九州大学学術情報リポジトリ

Kyushu University Institutional Repository

Observations of Pigment Accumulation in the Epithelium of the Shell Gland and Superficial Pigmentation on the Egg Shell in Japanese Quail

Soh, Tomoki

Laboratory of Animal Reproduction, Faculty of Agriculture, Kyushu University

Fujihara, Noboru

Laboratory of Animal Reproduction, Faculty of Agriculture, Kyushu University

Koga, Osamu

Laboratory of Animal Reproduction, Faculty of Agriculture, Kyushu University

https://doi.org/10.5109/24039

出版情報: 九州大学大学院農学研究院紀要. 38 (1/2)，pp.73-80，1993-12. Kyushu University バージョン：

権利関係 : 


\title{
Observations of Pigment Accumulation in the Epithelium of the Shell Gland and Superficial Pigmentation on the Egg Shell in Japanese Quail
}

\author{
Tomoki Soh, Noboru Fujihara and 0 samu Koga* \\ Laboratory of Animal Reproduction, Faculty of Agriculture, \\ Kyushu University 46-06, Fukuoka 812, Japan \\ (Received July 16, 1993)
}

\begin{abstract}
The pigment accumulation in the shell gland through an ovulation cycle and the pigmentation onto the surface of egg shell were observed in Japanese quail. The pigment granules and PAS-positive material in the apical cells of the epithelium of the shell gland increased progressively as time elapsed after ovulation and decreased suddenly 2-3 hrs before the expected oviposition as the pigmentation onto the egg shell occurred. The pigment granules and PAS-positive material secreted from the cells gathered to form pigment masses between folds of mucous membrane. The pigment masses were deposited on the surface of egg shell. After the pigmentation, only the PAS-positive material was seemed to be deposited on the surface to complete the cuticle.
\end{abstract}

\section{INTRODUCTION}

It has been shown that the superficial pigment (porphyrin) of a quail egg shell accumulates in the shell gland (uterus) with egg formation and is secreted 2 to $3.5 \mathrm{hrs}$ before oviposition (Woodard and Mather, 1964; Poole, 1965; Tanaka et al., 1977; Soh et al., 1989). The pigment granules are found microscopically in the apical cells of the epithelium in the shell gland (Tamura et al., 1965; Tamura and Fujii, 1966; Poole, 1967). The granules are observed in the periluminal region of the cells when the egg is in the isthmus and increase to the maximum amount associated with shell formation, and then they are secreted into the lumen of the shell gland (Tamura and Fujii, 1966). PASpositive granules, which are considered to form the cuticle of shell, are also observed in the apical cells (Tamura et al., 1965; Tamura and Fujii, 1966). The observation by the naked eye of the superficial pigmentation onto the quail egg shell through the shell gland wall reveals that the shell is dotted or spotted with pigments at the beginning of the deposition and that deposition of bulky pigments suddenly takes place $20 \mathrm{~min}$. after the beginning of deposition (Tanaka et al., 1977). However, the mucous membrane of the shell gland at the time of pigmentation has not yet been observed microscopically. In the present study, to clarify the time course of pigmentation onto the surface of the egg shell in Japanese quail, the mucous membrane of the shell gland was observed microscopically through an ovulation cycle.

*Present adress: Faculty of Agriculture, Kyushu Tokai University, Choyo-son, Aso-gun, Kumamoto $869-14$ 


\section{MATERIALS AND METHODS}

\section{Animals}

Quail hens (12-36 wks. of age) were maintained in individual cages and exposed to a 16-hr photoperiod (lights on from 0500 to 2100). The oviposition times were recorded according to the method of Soh et al. (1989). Feed (23\% CP; 2,800 kcal ME/kg) and water were available at all times. Hens laying midsequence eggs at nearly $24-\mathrm{hr}$ intervals were selected for the experiments.

\section{O bservations of pigmentation onto the surface of the egg shell}

Quail hens were anesthetized by injection of pentobarbital sodium solution $(50 \mathrm{mg} /$ ml) 2-3 hrs before the expected oviposition. Their shell glands were exposed by a longitudinal incision in the abdominal wall. The egg shell surface was observed in situ by the naked eye through the shell gland wall. Then quail hens were killed in pre-, midand post-pigmentation phases, referring to the report of Tanaka et al. (1977). Their shell glands with egg were excised and fixed in $10 \%$ formalin. After fixation, the shell glands were divided longitudinally into two equal pieces. The mucous membrane of the shell gland and the egg shell surface were observed macroscopically or stereomicroscopically.

\section{Microscopic observations of pigment granules in the epithelium through an ovulation cycle}

Quail hens were killed immediately after oviposition ( $30 \mathrm{~min}$. before ovulation), and 6,12 , and $20 \mathrm{hrs}$ after ovulation. Their shell glands with, if they had, egg were excised and fixed in $10 \%$ formalin. The histological specimens in pre-, mid-, and postpigmentation phases were also obtained from birds in the preceding method. The shell gland specimens were embedded in paraffin and were made into thin sections of $5 \mu \mathrm{m}$ in thickness. These sections were stained by conventional methods of hematoxylineosin or PAS-hematoxylin and observed microscopically.

\section{RESULTS}

\section{Observations of pigmentation onto the surface of the egg shell}

In the pre-pigmentation phase, no pigment was deposited on the egg shell surface (Fig. 1), and the mucous membrane of the shell gland showed dark brown (Fig. 2). In the mid-pigmentation phase, pigment masses were observed macroscopically in various sizes on the surface of the egg shell and the mucous membrane of the shell gland (Figs. 1 and 2). Stereomicroscopic observation revealed that large and fine pigment masses were observed not only on the surface but also between folds of mucous membrane (Fig. 3). In the post-pigmentation phase when the blotches on the surface of the egg shell were almost complete, the entire region of the shell gland showed a faint color (Fig. 2). 

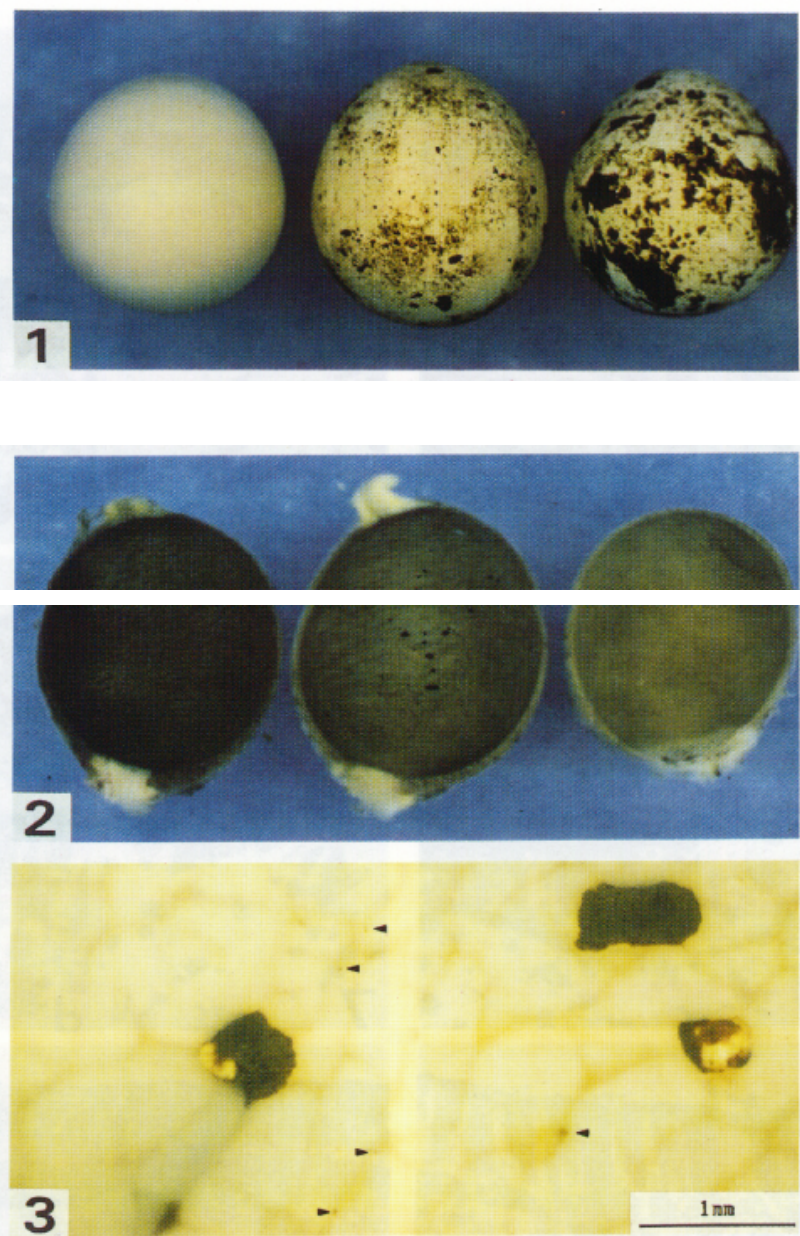

A photograph of the eggs, which were present in the shell glands 2 -

Fig. 1 .

before the expected oviposition. It shows pre-, mid-, and post-pigmentation phases from left to right.

Fig. 2. A photograph of the shell glands, from which the eggs shown in Fig. 1 were removed. Numerous pigment masses are observed on the mucous membrane at the mid-pigmentation phase (center).

Fig. 3. A stereomicroscopic photograph of the mucous membrane of the shell gland at the mid-pigmentation phase. Large pigment masses and many fine pigment masses (arrowheads) are observed between folds of the mucous membrane. 

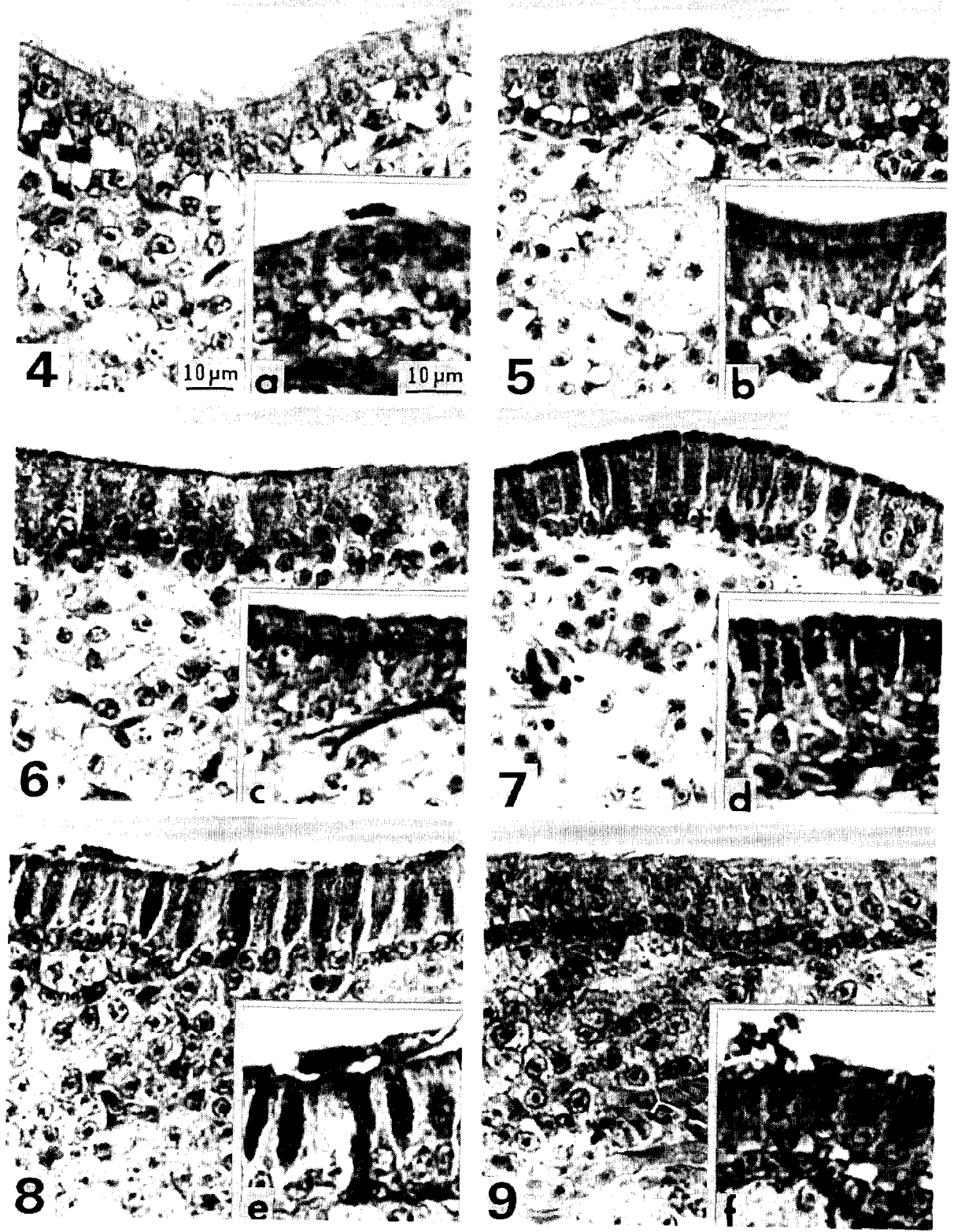

Figs. are microscopic photographs of the e p it lhematoxylin.of the $\mathrm{she} 1$ eosin, with same magnifications. The insets a-f are microscopic photographs of sections stained by PAS-hematoxylin, with same magnifications.

Fig. 4. The epithelium immediately after oviposition (30 min. before ovulation). Pigment granules are scarcely found in the apical cells. Inset a, there is a weak PAS reaction in the upper perinuclear region of the cells. Small pigment masses remaining on the surface of the epithelium are infrequently observed at this stage. 
Fig. 5. The epithelium $6 \mathrm{hrs}$ after ovulation. Some pigment granules become to be observed in the periluminal region of the apical cells compared to Fig. 4. Inset $b$, the periluminal and the upper perinuclear cytoplasm of the cells are PAS-positive.

Fig. 6. The epithelium $12 \mathrm{hrs}$ after ovulation. The pigment granules increase in the periluminal region of the apical cells. Inset $\mathrm{c}$, the PAS reaction of the periluminal region and the upper perinuclear region of the cells is more positive than that of inset $b$.

Fig. 7. The epithelium $20 \mathrm{hrs}$ after ovulation. A remarkable amount of pigment granules is observed in the apical region of the apical cells, which have become taller. Inset $\mathrm{d}$, strongly PAS-positive material is shown in the supranuclear cytoplasm of the cells.

Fig. 8. The epithelium in the mid-pigmentation phase (2-3 hrs before the expected oviposition). Pigment granules in the apical region of the apical cells decrease compared to those of Fig. 7. Secreted pigment granules are observed on the surface of the epithelium. Inset e, secreted pigment granules is positive to PAS reaction.

Fig. 9. The epithelium in the post-pigmentation phase (2-3 hrs before the expected oviposition). The pigment granules of the apical region of the apical cells has depleted. Inset $\mathrm{f}$, secreted PAS-positive material is present on the surface of the epithelium and the PAS reaction is shown in the upper perinuclear region of the cells.
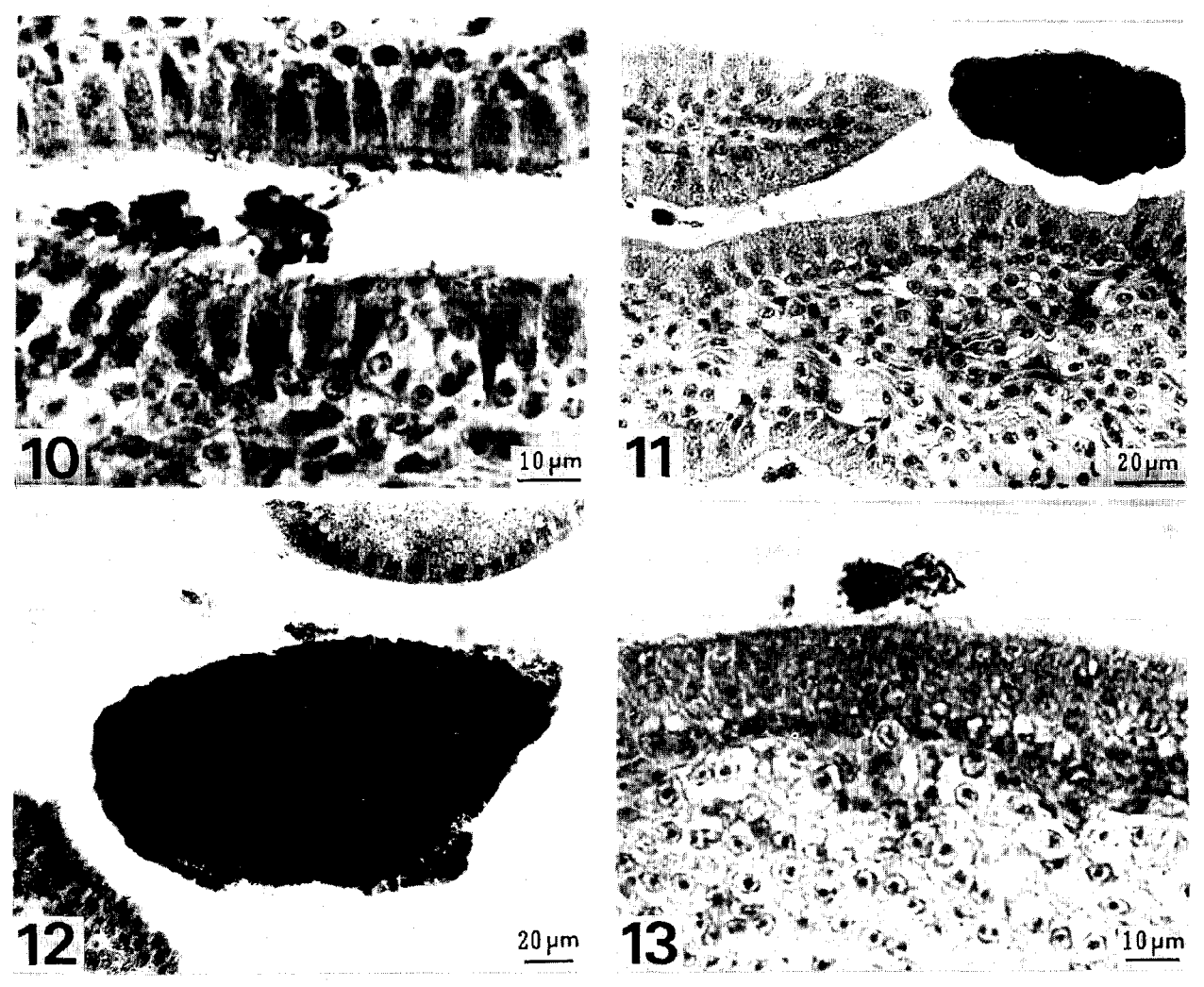

Figs. 10-13 are microscopic photographs of the epithelium and the cavity of the shell gland 2-3 hrs before the expected oviposition.

Fig. 10. The mid-pigmentation phase. Pigment granules that have been secreted into the cavity gather to form small pigment masses. Stained by_ hematoxylin-eosin.

Fig. 11. The mid-pigmentation phase. The pigment grown to be larger masses between folds are shown, Stained by hematoxylin-eosin.

Fig. 12. The mid-pigmentation phase. Large pigment masses between folds present positive to PAS reaction. Stained by PAS-hematoxylin.

Fig. 13. The post-pigmentation phase. Remaining pigment masses are frequently observed on the surface of the epithelium. Stained by hematoxylin-eosin. 


\section{Microscopic observations of pigment granules in the epithelium through an ovulation cycle}

The pseudo-stratified epithelium of the shell gland was composed of basal and apical cells. Pigment glanules were accumulated and secreted only by the apical cells, which showed various stages through an ovulation cycle.

Immediately after oviposition, the pigment granules, which were detected as black glanules in both staining methods, were scarcely observed in the apical cells of the epithelium (Fig. 4). A faint PAS reaction were observed close to the upper side of nucleus (inset a). Infrequently, small pigment masses left by the preceding egg were observed on the surface of the epithelium (inset a). The pigment granules appeared slightly in the periluminal region of the apical cells 6 hrs after ovulation (Fig. 5). PASpositive material was also observed in the periluminal region and the upper perinuclear region of the cells at this stage (inset b). The pigment granules in the periluminal region increased $12 \mathrm{hrs}$ after ovulation (Fig. 6) and the PAS reaction also intensified (inset c). A remarkable amount of pigment granules had been accumulated in the apical region of the cells $20 \mathrm{hrs}$ after ovulation (Fig. 7). Almost the whole supranuclear cytoplasm was strongly PAS-positive (inset d). The apical cells in this stage appeared as taller columnar cells. In the mid-pigmentation phase, the accumulated granules of the cells accompanied by PAS-positive material decreased and were secreted on the surface of the epithelium (Fig. 8 and inset e). In the postpigmentation phase, almost all pigment granules disappeared from the apical cells (Fig. 9). On the other hand, secreted PAS-positive material on the surface of the epithelium and the PAS reaction in the upper perinuclear region were still observed (inset f).

\section{Microscopic observations of pigment masses on the surface of the mucous membrane}

From microscopic observation of the mucous membrane in the mid-pigmentation phase, it was indicated that the pigment granules secreted from the apical cells gathered at first to be small masses (Fig. 10). These small masses grew to be larger between folds of the membrane (Fig. 11). These masses also contained the PASpositive material (Fig. 12). In the post-pigmentation phase, small pigment masses frequently remained on the surface of the mucous membrane (Fig. 13).

\section{DISCUSSION}

In the shell gland of Japanese quail, the pigment granules are observed in the apical region of apical cells of the epithelium (Tamura et al., 1965; Tamura and Fujii, 1966; Poole, 1967). The present study showed corresponding results with previous studies. The pigment granules appeared about $6 \mathrm{hrs}$ after ovulation and reached to the maximum amount until $\mathbf{2 0} \mathrm{hrs}$ after ovulation. These histological observations on the pigment accumulation exhibit the similar process to the quantitative change of pigment in the shell gland (Soh et al., 1989).

The macroscopic observation of superficial pigmentation on the shell of quail egg reveals that the egg is dotted or spotted with pigment at the beginning of deposition (Tanaka et al., 1977). Similarly, Woodard and Mather (1964) have described "the presence of numerous droplets of pigment in the uteral lumen of the coturnix at the 
time of pigmentation." From the present results, pigment masses appeared on the surfaces of the mucous membrane and they were deposited onto the egg shell in the midpigmentation phase. Microscopically, it was also showed that pigment granules secreted from the apical cells gathered to form larger masses between folds of mucous membrane. It is assumed that the pigment masses are deposited at first as dots and then spread into blotches on the shell surface by contractions of the shell gland and rotation of the egg, as suggested by Tanaka et al. (1977). Small pigment masses remaining on the surface of the mucous membrane in the post-pigmentation phase or immediately after oviposition may be excreted through the vagina.

The PAS-positive material in the apical cells of epithelium increased after ovulation and was secreted from the cells in the mid-pigmentation phase. The PAS stained specimens also indicated that the positive material mingled with the pigment in the lumen of the shell gland. These results agree with the report of Tamura and Fujii (1966). The heavy viscosity of the superficial pigment on the egg shell immediately after completing pigmentation (Tanaka et al., 1977) suggests that PAS-positive material plays a paste-like role in forming pigment masses and depositing them onto the shell surface. The PAS-positive material is also considered as cuticular material (Tamura et al., 1965; Tamura and Fujii, 1966). Histochemically, the PAS-positive material in the apical cells is presented as a neutral mucopolysaccharide-protein complex (Tamura and Fujii, 1966). The cuticular layer contains neutral sugars and is stained by PAS reaction (Tamura, 1971). It is suggested that the pigment and PAS-positive granules in the apical cell are secreted into lumen to form the cuticle (Tamura and Fujii, 1966). These reports and the present results suggest the simultaneous commencement of superficial pigmentation and cuticular formation on the quail egg shell. This suggestion is supported by the evidence that the shell surface of quail egg is almost white or colored in light greenish-blue after removing cuticle (Tamura and Fujii, 1967). Secreted PASpositive material was present on the surface of the epithelium of the shell gland in the post-pigmentation phase. This observation suggests that the PAS-positive material is still deposited on the surface of the egg shell following pigmentation and completes the cuticle.

\section{ACKNOWLEDGEMENTS}

We greatly appreciate technical advice from Dr. Y. Yoshimura at the Faculty of Applied Biological Science, Hiroshima University and Dr. T. Mōri at the Department of Animal Science, Faculty of Agriculture, Kyushu University.

\section{REFERENCES}

Poole, H. K. 1965 Spectrophotometric identification of eggshell pigments and timing of superficial pigment deposition in Japanese quail. Proc.Soc. Exp.Biol. Med., 119: 547-551

Poole, H. K. 1967 A microscopic study of uterine eggshell pigment in Japanese quail. J.Hered., 58: 200 -203

Soh, T., 0. Koga, and T. Tanaka 1989 Research Note: Involvement of ovulation mechanism(s) in 
the accumulation of pigment in the shell gland of the Japanese quail (Coturnix coturnix japonica). Poultry Sci., 68: 1156-1158

Tamura, T. 1971 Histological studies on formation of egg-covering in quail oviduct. J.Fac. Fish. Anim. Husb. Hiroshima Univ., 10: 1299137

Tamura, T. and S. Fujii 1966 Histological observations on the quail oviduct; on the secretions in the mucous epithelium of the uterus. J. Fac. Fish. Anim. Husb. Hiroshima Univ., 6: 357-371

Tamura, T. and S. Fujii 1967 Comparative observations on the distribution of fluorescent pigments (porphyrins) in the egg-coverings of chickens and quail. J. Fac. Fish. Anim. Husb. Hiroshima Univ., 7: 35-41

Tamura, T., S. Fujii, H. Kunisaki, and M. Yamane 1965 Histological observations on the quail oviduct; with reference to pigment (porphyrin) in the uterus. J.Fac. Fish. Anim. Husb. Hiroshima. Univ., 6: 37-57

Tanaka, K., T. Imai, and 0. Koga 1977 Superficial pigmentation of egg shell in Japanese quail, Coturnix coturnix japonica. Jpn.Poult.Sci., 14: 229-231

Woodard, A. E. and F. B. Mather 1964 The timing of ovulation, movement of the ovum through the oviduct, pigmentation and shell deposition in Japanese quail (Coturnix coturnix japonica). Poultry Sci., 43: 1427-1432 